\title{
A NON-PARAMETRIC ANALYSIS OF TECHNICAL EFFICIENCY IN BULGARIAN FARMS USING THE FADN DATASET
}

Nicola Galluzzo ${ }^{1}$

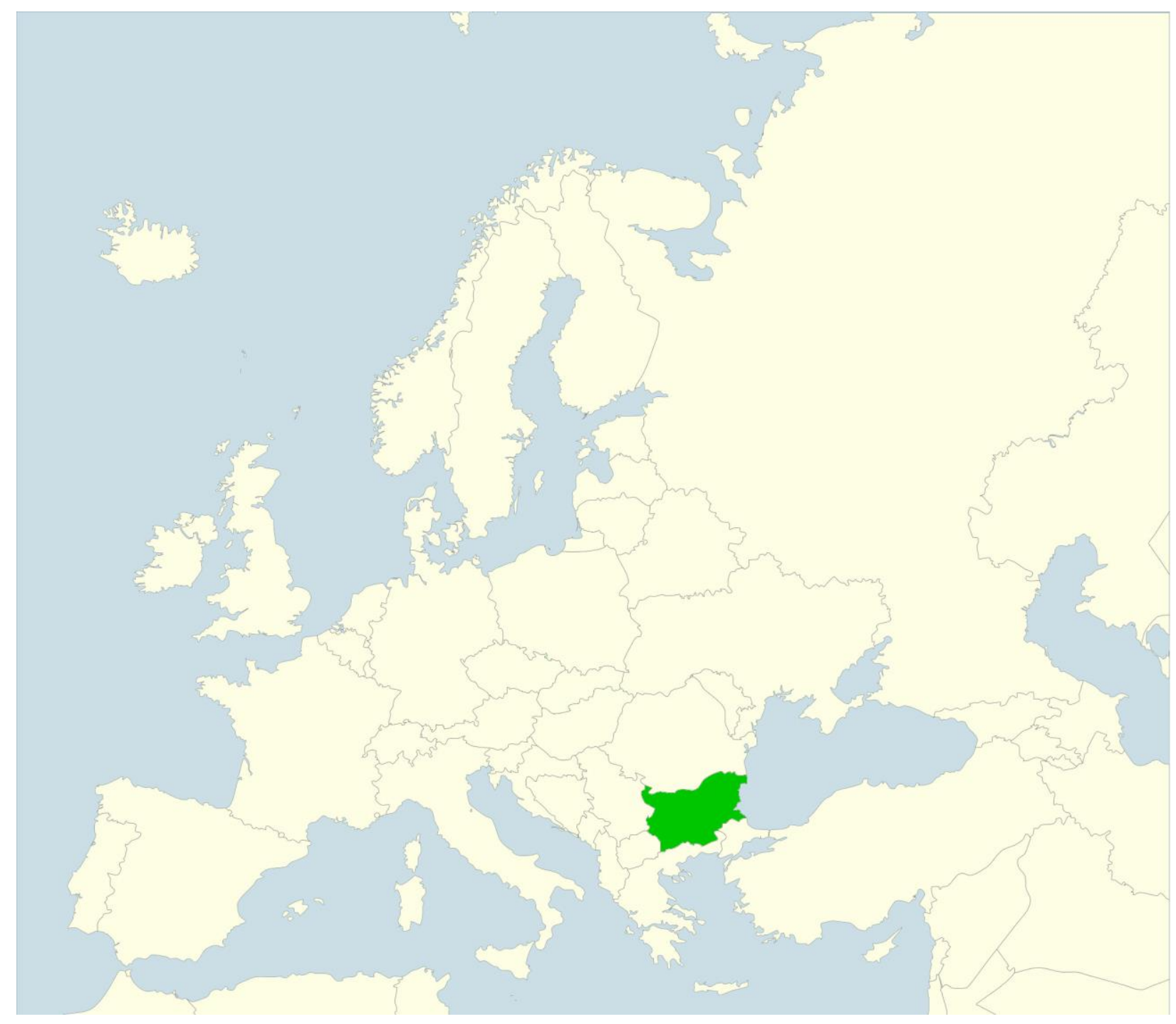

${ }^{1}$ Dr. Nicola Galluzzo Ph.D., Director of ASGEAR, Association of Geographical and Economic Studies of Rural Areas, Via Salaria per L'Aquila, 76 scala A, 02100 Rieti, Italy, email: asgear@libero.it 
Abstract: The Bulgarian countryside has suffered a significant phenomenon of rural emigration since the early 1970s. The main consequence of rural depopulation has been a decline of investments in Bulgarian farms and in their own level of technical and economic efficiency. The aim of this research was to assess afterwards the enlargement of the European Union in 2007, the technical efficiency by a nonparametric approach such as the Data Envelopment Analysis (DEA), using some findings and variables investigated in the Farm Accountancy Data Network annual survey from 2007 till 2015. Farms have been stratified into functions of their typology of farming and their geographical localization. Research findings have pointed out that specialized farms as dairy farms and granivores ones have had the highest levels of technical efficiency compared to mixed farms and wine farms. To sum up, financial subsidies allocated by the Common Agricultural Policy have had a positive impact towards farmers, both increasing the technical efficiency and also in reducing the socio-economic marginalization of Bulgarian rural areas.

Keywords: Common Agricultural Policy, typology of farming, rural areas, emigration, Data Envelopment Analysis.

\section{Introduction}

Bulgaria is one of the most recent newcomer member states of the European Union and its transition from a centralized economy to an open one as a consequence of the collapse of the Communist regime has implied serious economic and financial problems in the late 1990s. All this has implied a fundamental reform process in the sphere of agricultural national policy and towards farms aimed at implementing their technical and economic efficiency in order to be more competitive and efficient in the international and European market (Davidova, 1991).

More than $20 \%$ of Bulgarian population work in agriculture even if a significant percentage of total agricultural surface is not cultivated; focusing the attention on the main cultivations, there is a high incidence of cereals on the total cultivated crops. According to FAO country facts sheet, more than $26 \%$ of people are assembled by rural population scattered in lots of small villages. Land fragmentation is typical of Bulgarian farms and it is also one of the most downside in farm efficiency and in farm income, with the consequence to foster the rural emigration from the countryside with significant impacts on the biodiversity (Di Falco et al., 2010).

Before the enlargement of the European Union in 2007, Bulgaria has benefited from the financial funds allocated in supporting the pre-accession phase of EU enlargement that is able to make the agrarian fabric more competitive and efficient than before, improving socioeconomic growth and also in increasing employment opportunities (Manos et al., 2013) with several impacts in farm technical and economic efficiency.

In literature review, research findings have underlined that the social capital, the age of farmers and people living in the countryside and farm managed by woman in some new member states, have acted on the improvement of farms efficiency (Mathijs and Vranken, 2001). At the same time, other studies have argued that the property of farm, the size of enterprises, in terms of usable agricultural areas and typology of management and ownership, have acted on the level of technical and economic efficiency in farms (Galluzzo, 2015a; 2015b; Latruffe and Nauges, 2014; Latruffe et al., 2004; Latruffe, 2010; Latruffe et al., 2005; Bojnec and Latruffe, 2008; Davidova and Latruffe, 2007; Bakucs et al., 2010; Latruffe et al., 2012; Guyomard et al., 2006). As previously mentioned, in many European countries, the property plays an important role and function towards smallholder farmers, that have got tiny units of production, fragmented and sparsely located in the countryside considered wrongly because of their dimension, technically and economic inefficient as argued and assessed in other European countries by several authors (Galluzzo, 2013; 2015a; Camelia and Vasile, 2016). 
A literature review has investigated before and after the enlargement of the European Union, the technical and economic efficiency in farms, addressing their analysis in investigating some relationships among technical and economic efficiency and other variables such as farm net income, dimension of farm, crop specialization and financial subsidies allocated by the Common Agricultural Policy (Galluzzo, 2015a; 2015b; 2016; Camelia and Vasile, 2016; Latruffe et al., 2004; Latruffe, 2010; Latruffe et al., 2005; Bojnec and Latruffe, 2008; Davidova and Latruffe, 2007; Bakucs et al., 2010; Latruffe et al., 2012; Guyomard et al., 2006). Some of these latter authors have argued that the most critical downside of small farms is intrinsic in their modest land capital endowment in terms of usable agricultural areas mainly fragmentized in several poor plots of land, which does not allow a squeezing in input costs throughout a more efficient use of productive factors, such as capital land and labor capital. By contrast, other studies in Italy and in new comer member state of the European Union such as Romania and Italy, have pointed out that big farms should be considered more efficient than small enterprises (Galluzzo, 2015a; 2015b; 2016). In particular, if the ownership is in the hands of limited companies or coops, the level of assessed efficiency seems to be better than family small farms (Galluzzo, 2013; Camelia and Vasile, 2016; Kopeva et al., 2012; Kaneva, 2016). Therefore, among variables such as property of farm, dimension of usable agricultural area and economic and technical efficiency, there is a positive correlation and a direct nexus (Bravo-Ureta et al., 2007; Chavas and Aliber 1993; Galluzzo, 2016).

Focusing the attention on the dataset used in the assessment of efficiency, in many European countries, several studies have investigated in depth the technical and economic efficiency by a non-parametric approach using the Farm Accountancy Data Network (FADN) dataset, or sometimes focusing the target of study towards few specific case studies assessed in a sample of European farms located in different nations (Vēveris et al., 2007; Latruffe et al., 2012; Galluzzo, 2015b; Marongiu et al., 2010; Bojnec and Latruffe, 2008; Mathijs and Swinnen, 2001). Other authors have also investigated if there are quantitative connections among the variable farm size, cropping specialization, typology of farming and the level of technical and economic efficiency in different European countries assessing several nexus between the geographical location of farms, and their own technical and economic efficiency (Bojnec and Latruffe 2009; Bielik and Rajcaniova 2004; Latruffe et al. 2004; Cesaro et al., 2009; Marongiu et al., 2010; Kumbhakar, 1993; Galluzzo 2013; 2016; Mathijs and Swinnen, 2001) or among typology of farming, farm's location in terms of altimetry and efficiency (Marongiu et al., 2010; Cesaro et al., 2009). Findings have pointed out that small farms and in particular small family farms maximise better labour inputs by a diversification in their own agrarian process of cultivation and reducing the socio-economic marginalization in territories at risk of a fatal rural emigration (Gorton and Davidova 2004; Bojnec and Latruffe 2008; Bielik and Rajcaniova 2004; Latruffe et al., 2004).

Recent research findings about the analysis of efficiency in Bulgarian farm by the DEA approach have pointed out that labour and land capital are pivotal variables in farm's efficiency (Kaneva, 2016). Previous studies carried out in Bulgaria by Mathijs et al. in 1999 have emphasized the role of ownership and typology of management in improving the efficiency of farms (Kaneva, 2016). By contrast, other authors have stratified a sample of farms into functions of their productive specialization, assessing the technical efficiency in corporate farms considering also their own crop productions (Mathijs \& Vranken, 2001; Gorton and Davidova, 2004).

In general, outcomes of technical efficiency analysis in more specialised farms such as dairy farms, have pointed out significant levels of imbalances among European countries (Guth, 2015). Addressing the analysis in Bulgaria, estimating in the same time the typology of farm and their productive specialization in Bulgarian farms, findings have assessed the best results in farms specialized in granivores and in other grazing livestock, by contrast, modest values have been estimated in permanent crops and horticulture farms (Kaneva, 2016). Furthermore, in Bulgaria and in other new member states of the European Union, the technical efficiency has been unstable both over the time and also in function of their own farming typology and productive specialization, which is predominately market oriented (Bachev, 2017). Other authors have argued that the farm size and the typology of production in farms are two most important factors in driving both the technical efficiency and also the management of farms, 
even if in influencing the level of technical efficiency in farms fundamental, it has been the role of financial subsidies allocated by the Common Agricultural Policy (Latruffe and Nauges, 2014; Latruffe et al., 2017; Domanska et al., 2014; Turčeková et al., 2015; Záhorský and Pokrivčák, 2016).

\section{Aim of the research}

In literature review, several studies have investigated relationships between farm dimension and efficiency using one of the most important variable driving the technical efficiency, the cropping specialization and the typology of breeding (Garcia et al., 1982; Galluzzo, 2015a, 2015b; Paul et al., 2004; Marongiu et al., 2010; Latruffe et al., 2004; 2012) in a multi-output or in a multi-input methodology (Bojnec and Latruffe, 2009).

In Bulgaria, only few studies only have assessed in depth the relationships between farms specialization and efficiency in a sample of farms part of FADN dataset, using the DEA approach (Kaneva, 2016; Mathijs \& Vranken, 2001). In contrast, other authors have investigated and compared the technical efficiency in many European countries by the Data Envelopment Analysis and by the Malmquist productivity index over a short period of time (Záhorský and Pokrivčák, 2016). Findings of these authors have pointed out good performances in terms of technical efficiency due to farm subsidies and farms size, which are fundamental variables able to impact on the level of efficiency with positive effects in Bulgaria and in other member states belonging to the European Union (Záhorský and Pokrivčák, 2016). At the same time, other authors more recently have focused their efforts in estimating the level of technical efficiency in all European countries and in new comer member states emphasizing an increase of technical efficiency in farms but in any case, this growth in technical efficiency has been lower than the European average value recently estimated by different scholars (Kočišová, 2015; Nowak et al., 2015; Laurinavičius and Rimkuvienè, 2017).

With the purpose to assess the impact of the Common Agricultural Policy towards farmers in different European Countries, the European Economic Community in 1965 by the Council Regulation number 79 has set up an annual survey on a sample of farmers called, Farm Accountancy Data Network or FADN.

The aim of this analysis was to assess the technical efficiency in a sample of Bulgarian farms belonging to the Farm Accountancy Data Network (FADN) from 2007 to 2015 stratifying farms into 3 main clusters in function of their typology of farming (TF), year of investigation and geographical localization assessing which Bulgarian regions NUTS 2 is more efficient than the other ones.

The reason for setting up three clusters was to evaluate which typology of farming has been more efficient as estimated in Bulgaria by other scholars, assessing if the more specialized the agricultural enterprise is, the more technical and economic efficient the farm is (Kaneva, 2016; Mathijs \& Vranken, 2001). Furthermore, the time series analysis has been useful in comparing over the time of investigation the evolution of the technical efficiency in Bulgarian farms part of the FADN dataset. Comparing different Bulgarian regions, classified following the criteria proposed by the European Union in the NUTS classification, it has been possible to estimate which regions are characterized by farms more efficient than others.

The classification of typology of farming in this research was done in accordance with the guidelines proposed by the European Commission Decision and promulgated in 2003 as: specialist COP (cereals, oilseed and protein crops), specialist other field crops, specialist horticulture, specialist vineyards, specialist orchards-fruits such as specialist fruit and citrus fruit, specialist olives (for example, various permanent crops combined), specialist milk (milk and cattle rearing), specialist sheep and goats, specialist cattle as specialist cattle-rearing and fattening, cattle rearing, cattle fattening and cattle-dairying, rearing and fattening combined, specialist granivores (pigs and poultry), mixed crops, mixed livestock and mixed crops and livestock. 


\section{Methodology}

In order to study the efficiency, there are two methods: a parametric or deterministic approach, which needs a specific function of production and other parametric variables correlated to the factors of production, and a non-parametric model or DEA (Data Envelopment Analysis), whose purpose is to define a hypothetical function of production and the distance from the frontier of this function is the index of technical inefficiency or technical efficiency (Bielik and Rajcaniova 2004). In fact, along this function, all the possible combinations of inputs or output are able to minimize costs or maximize the income.

In the non-parametric model, fluctuations from the frontier of the function of production are considered no efficient and they are not connected to the errors thus, the technical efficiency is described as a set of opportunities for farmers able to maximize the output minimizing in the same time inputs or vice versa (Bojnec and Latruffe 2008). The economic efficiency has been estimated by a non-parametric model applied to specific assumptions of a variable return to scale or VRS in an input oriented model (Farrell, 1957; Battese 1992; Coelli 1996) using DEAP 2.1 software comparing it to a constant return to scale or CRS.

The purpose of DEA linear programming model is to minimize in a multiple-output model the multiple-input in each farm which is a ratio of efficiency and in a mathematical model it can be written (Papadas and Dahl, 1991):

$\max h=\Sigma_{r} u_{r} y_{r j o} / \Sigma_{i} v_{i} x_{i j o}$

s.t.

$\sum_{r} u_{r} y_{r j} / \sum_{i} v_{i} x_{i j} \leq 1$

$\mathrm{j}=0,1, \ldots . . \mathrm{n} \quad$ (for all $\mathrm{j})$

$u_{r}, v_{i} \geq 0$

In term of productivity, if there are two farms or Decision Making Units (DMUs) such as A and B capable of producing two levels of output such as $y_{a}$ or $y_{b}$, using a specific quantity of input as $x_{a}$ and $x_{b}$, the productivity is a simple ratio between produced output on used input $y a / x_{a}$ and $y_{b} / x_{b}$.

The non-parametric linear model throughout the Data Envelopment Analysis has been described for the first time in 1978 (Charnes et al., 1978) and it is useful to estimate the relative efficiency in each Decision Making Units based on different levels of input and output (Hadad et al., 2007), with the purpose to minimize the level of input in the process of production (Doyle and Green 1994).

The aim of a non-parametric input-oriented model, used in this research is to minimize in a multiple-output model the multiple-input in each farms part of the FADN Bulgarian database, which is a ratio of efficiency with numerous possible solutions hence, the value of efficiency is in range between 0 and 1 (Bhagavath 2009; Galluzzo, 2013; 2016). If $h$ or rather the value of efficiency is equal to 1 or $100 \%$, each farm or Decision Making Unit (DMU) is more efficient compared to other $\mathrm{DMUh}_{\mathrm{n}}$ which have a value of efficiency closest but not equal to 1 or $100 \%$ (Bhagavath, 2009). In order to find the best Decision Making Unit in this research, it is fundamental to use a linear function by a linear programming methodology called CCR (Charnes and Cooper 1962; Bhagavath, 2009) written in this way:

$\max h=\Sigma_{r} u_{r} y_{r j o}$ 
s.t. dual variable

$\Sigma_{\mathrm{i}} \mathrm{V}_{\mathrm{i}} \mathrm{X}_{\mathrm{ijo}}=100 \% \mathrm{Z}_{\mathrm{o}}$

$\Sigma_{r} u_{r} y_{r j o}-\Sigma_{i} v_{i} x_{i j o} \leq 0$ with $j=0,1, \ldots n$ (for all $\left.j\right) \lambda_{j}$

$-v_{i} \leq-\varepsilon i=0,1, \ldots . m$ and $\varepsilon$ is a positive value $s_{i}^{+}$

$u_{r} \leq-\varepsilon \quad r=0,1, \ldots t$ and $\varepsilon$ is a positive value $s_{r}$

In the dual problem, it is important to consider a dual variable in each constraint in the primary model (Charnes et al., 1978) written as:

$\min 100 \% Z_{o}-\varepsilon \Sigma_{i} S_{i}^{+}-\varepsilon \Sigma_{r} S_{r}^{-}$

s.t.

$\Sigma_{\mathrm{j}} \lambda_{\mathrm{j}} \mathrm{x}_{\mathrm{ij}}=\mathrm{x}_{\mathrm{ijo}} \mathrm{Zo}-\mathrm{s}_{\mathrm{i}}^{+} \mathrm{i}=0,1, \ldots \mathrm{m}$

$\Sigma_{\mathrm{j}} \lambda_{\mathrm{j}} \mathrm{x}_{\mathrm{rj}}=\mathrm{y}_{\mathrm{rj} 0}+\mathrm{s}_{\mathrm{r}}^{-} \quad \mathrm{r}=0,1, \ldots . \mathrm{t}$

$\lambda_{\mathrm{j}}, \mathrm{Si}^{+}, \mathrm{S}_{\mathrm{r}}^{-} \geq 0$

$\lambda_{\mathrm{j}}$ are shadow prices able to reduce the efficiency in each unit lower than 1 or $100 \%$ and a positive value of $\lambda_{j}$ is able to assess a peer group in some inefficient unit.

In this research, it has used an input-oriented DEA method aimed at estimating the quantity of input that can be reduced when the quantity of output is constant (Laurinavičius and Rimkuvienè, 2017). The constant return to scale technical efficiency (CRSTE) implies as an increase in input is able to implement the same quantity of output by contrast in the variable return to scale technical efficiency (VRSTE) an increase of output is able to increase in a different proportion the input hence, if output increases less than the input, there is a decreasing return to scale or drs otherwise there is an increasing return to scale or irs (Laurinavičius and Rimkuvienè, 2017).

The purpose of the input oriented method used in this research is to maximize the output using a modest level of input (Charnes et al., 1978; Farrell, 1957; Battese 1992; Coelli 1996):

$\max z=\Sigma p_{n} y_{n o}+k$

$\mathrm{p}, \mathrm{m} \quad \mathrm{n}$

s.t.

$\Sigma p_{n} y_{n j}-\Sigma m_{i}-y_{i j} \leq b \Sigma m_{i} x_{i 0}=1$ 
$p_{r}, m_{i} \geq 0 \quad i=0,1,2, \ldots \ldots, n$

The dual problem in a matrix transformation is solved by a mathematical expression and changing parameters $h$ and $k$ in (5) and in (8), it is possible to obtain if $h$ is equal to 0 a frontier with constant return to scale, otherwise if $h \geq 0$ or $h \leq 0$, it is impossible to accept a function with increasing return to scale or it is not possible to accept a function with the consequence to generate a decreasing return to scale function written in mathematical terms as:

$\min \theta$

$\theta, \mathrm{h}$

s.t.

$\theta \mathrm{X}_{0}-\mathrm{hX} \geq 0$ and $h \mathrm{Y} \geq \mathrm{Y}_{0}, \mathrm{~h} \geq 0$

In this research, the output variable in the DEA model has been made by the farm net income instead of the input variables consisted of labour capital, land capital, specific costs for seed and plants, fertilizers and crop protection, total farming overhead, total assets, financial subsidies allocated by the first and by the second pillar of the Common Agricultural Policy such as less favoured payments, financial subsidies for the rural development and decoupled payments.

\section{Results}

Since 1950, findings of FAO time series of people have pointed out a sharp increase of Bulgarian population until the collapse of Communist regime which in 1990 has reached the peak of 9 million people (Fig. 1); afterwards, there has been a constant drop of people living in Bulgaria predominately due to a severe emigration phenomenon. Comparing the evolution of rural and urban population in 1970, the urban population has overcome the rural one, which has declined constantly fostering the socio-economic marginalization in Bulgarian countryside, intensifying the land fragmentation and the ageing of rural population.

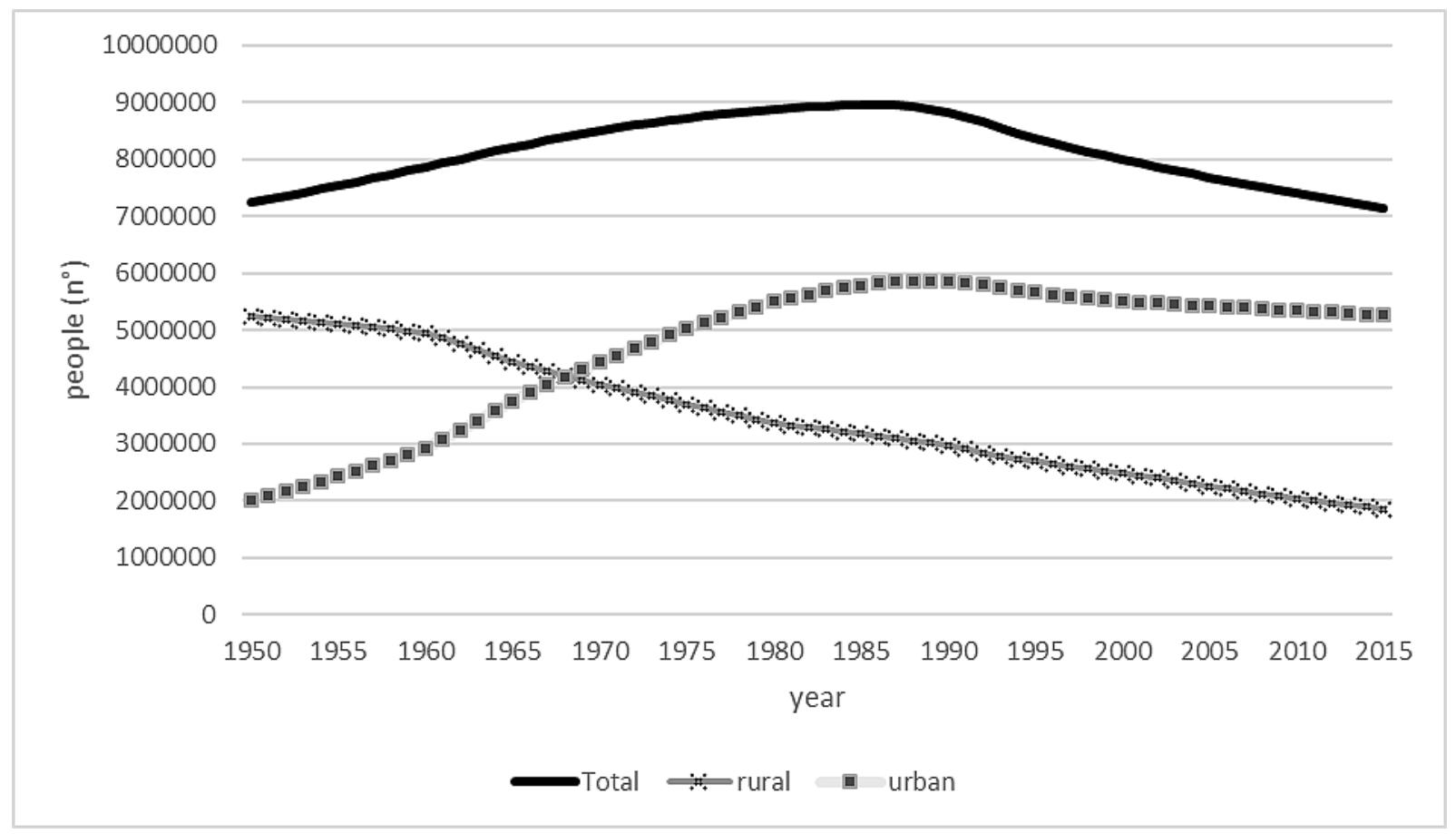

Fig 1. Evolution of Bulgarian population and its distribution between rural and urban territories. Source: elaboration on data FAO published on the website Faostat 
According also the Eurostat time series, the Bulgarian Gross Domestic Products in the primary sector in current value has pointed out an unstable evolution over time reaching the peak in 2008 after the enlargement of the European Union in 2007 and it had a constant increase after the economic recession since 2010 to 2014 (Fig. 2).

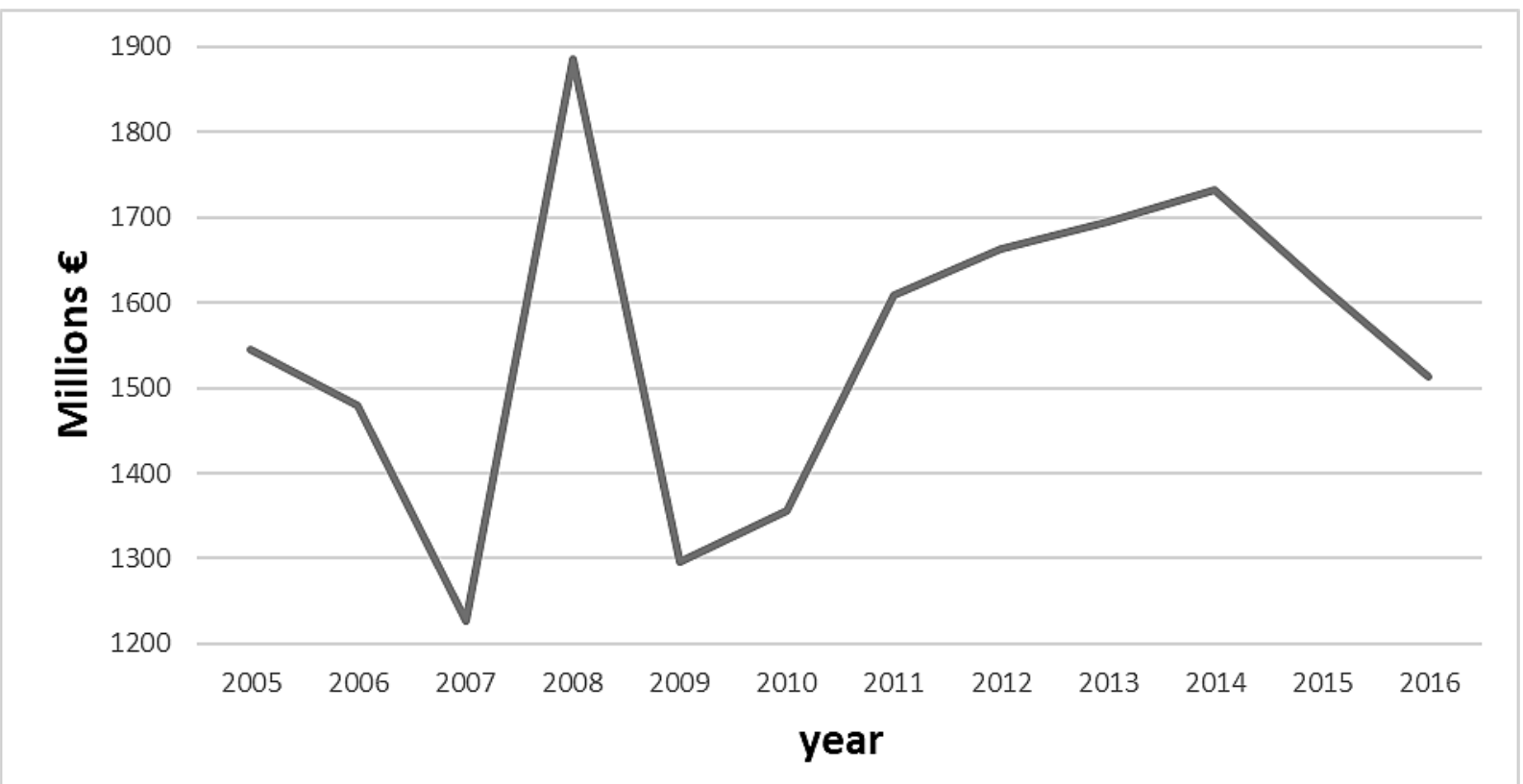

Fig 2. Evolution of Gross Domestic Product in the primary sector in Bulgaria. Source: elaboration on data Eurostat

Tab 1. Evolution of farms and agricultural area in Bulgaria. Source: Eurostat

\begin{tabular}{|c|c|c|c|}
\hline Year & $\begin{array}{c}\text { Farms } \\
\left(\mathbf{n}^{\mathbf{0}}\right.\end{array}$ & $\begin{array}{c}\text { Utilised agricultural area } \\
\text { (ha) }\end{array}$ & $\begin{array}{c}\text { Mean surface } \\
\text { (ha) }\end{array}$ \\
\hline 2005 & 534,610 & $2,729,390$ & 5.10 \\
\hline 2007 & 493,130 & $3,050,740$ & 6.18 \\
\hline 2010 & 370,490 & $4,475,530$ & 12.08 \\
\hline 2013 & 254,410 & $4,650,940$ & 18.28 \\
\hline
\end{tabular}

Tab 2. Main features of Bulgarian agriculture. Source: Eurostat

\begin{tabular}{|l|c|c|c|c|}
\hline \multicolumn{1}{|c|}{ Variable } & \multicolumn{4}{c|}{ year } \\
\hline Farms $<5$ ha & $\mathbf{2 0 0 5}$ & $\mathbf{2 0 0 7}$ & $\mathbf{2 0 1 0}$ & $\mathbf{2 0 1 3}$ \\
\hline Total farms & 497,111 & 456,630 & 325,350 & 211,450 \\
\hline Standard output $<4,000 €$ & 534,610 & 493,130 & 370,490 & 254,410 \\
\hline Standard output 15,000-49,000 & 464,550 & 428,280 & 314,590 & 191,600 \\
\hline Standard output 4,000-14,999 & 7,980 & 8,820 & 10,810 & 13,100 \\
\hline Farms with the age of holder $<35$ years & 57,640 & 50,830 & 38,800 & 41,400 \\
\hline Farms with the age of holder $>65$ years & 21,970 & 15,050 & 25,010 & 15,830 \\
\hline Farms with the age of manager $<35$ years & 222,190 & 221,890 & 137,800 & 93,000 \\
\hline Farms with the age of manager $>65$ years & 22,270 & 15,320 & 25,540 & 16,300 \\
\hline
\end{tabular}


Tab 3. Technical efficiency evolution over the time in Bulgarian farms part of FADN. Source: elaboration on data http://ec.europa.eu/agriculture/rica/database/database_en.cfm

\begin{tabular}{|c|c|c|c|c|}
\hline year & $\begin{array}{c}\text { Constant return } \\
\text { to scale technical } \\
\text { efficiency } \\
\text { (CRSTE) }\end{array}$ & $\begin{array}{c}\text { Variable return to } \\
\text { scale technical } \\
\text { efficiency } \\
\text { (VRSTE) }\end{array}$ & $\begin{array}{c}\text { Scale } \\
\text { efficiency }\end{array}$ & $\begin{array}{c}\text { Type of } \\
\text { return } \\
\text { to scale }\end{array}$ \\
\hline 2007 & 1 & 1 & 1 & - \\
\hline 2008 & 1 & 1 & 1 & - \\
\hline 2009 & 1 & 0.899 & 0.99 & drs \\
\hline 2010 & 0.89 & 0.878 & 0.991 & irs \\
\hline 2011 & 0.87 & 0.98 & 0.875 & irs \\
\hline 2012 & 0.857 & 0.9 & 0.892 & irs \\
\hline 2013 & 0.803 & 1 & 0.957 & - \\
\hline 2014 & 0.957 & 1 & 1 & \\
\hline 2015 & 1 & 0.962 & 0.967 & \\
\hline mean & 0.931 & 1 & & \\
\hline
\end{tabular}

drs stands for decreasing return to scale and irs stands for increasing return to scale

In Bulgaria, there has been a significant reduction of farms which halved in eight years comparing the data published in 2013 to those published in 2005, and an increase of usable agricultural areas (Tab. 1) with a direct impact on the average surface that, according to the recent data published by Eurostat, has been three time higher than the data assessed in 2005.

In general, the agrarian productive fabric is represented by small family farms and more of them have got an agricultural area lower than 5 hectares sometimes fragmented and it is predominately managed and owned by a farmer with an age between 55 to 65 years old (Tab. 2). During the time of investigation, there was a drop in young farmers even if findings have pointed out significant fluctuations and a significant drop in 2013. Extracting by the Eurostat, values of the variable Standard Output in Euro have highlighted that more than $80 \%$ of Bulgarian farms have an amount of output lower than 4,000 Euro and it is increased over the time of investigation of farms with a level of standard output between 15,000 to 49,000 euro.

Findings, both in constant return to scale (CRTS) and also in variable return to scale (VRTS), have pointed out that Bulgarian farms part of the FADN have had a value close to 1 of technical efficiency; in general, in four years out of nine, technical efficiency has been close to 1 (Tab. 3). The lowest value has been pointed out in 2013 and in 2012. Assuming the variable return to scale, Bulgarian farms have been more technically efficient in five years out of nine; in particular in the last year of investigation (2015), there has been an increase of technical efficiency of farms part of the FADN dataset. The increase return to scale (irs) on the variable return to scale (VRS) frontier in the DEA model was assessed in 4 years out of 9; the increase return to scale implies that a modest increase of input is correlated to a more intense increase of output. In 2010 only, outcomes have highlighted a decreasing return to scale hence, the increase in output has been less modest than the increase in used input. Focusing the attention on the average value of technical efficiency over the time of investigation, Bulgarian farms have not been efficient because the value has been lower than the threshold of 1 .

The research findings in technical efficiency compared to others assessed by some authors in 2004 and in 2005 in all European countries by a CRS and a VRS approach, respectively equal to 0.80 and 0.87 , have pointed out a significant increase of efficiency in Bulgarian farms 
(Záhorský and Pokrivčák, 2016). The value of technical efficiency close to the optimal threshold but above the best value equal to 1 , has also corroborated other outcomes of technical efficiency assessed in new member states by previous studies with significant decreases in 2010 and 2011, respectively equal to 0.88 and 0.93 , with a transition from an efficient phase to an inefficient one (Bojnec et al., 2014; Kočišová, 2015). In any case, technical efficiency assessed in Bulgarian farms part of the FADN dataset has been above the average value estimated in all 27 European countries in recent analysis by other scholars (Nowak et al., 2015; Laurinavičius and Rimkuvienè, 2017).

Focusing the attention to the relationships among typology of farming and efficiency, outcomes have underlined better results in variable return to scale (VRSTE) than in constant return to scale model (Tab. 4). Hence, an increase in input is able to increase the output in a different proportion.

Tab 4. Technical efficiency in Bulgarian farms part of FADN stratified into function of their typology of farming. Source: elaboration on data http://ec.europa.eu/agriculture/rica/database/database_en.cfm

\begin{tabular}{|l|c|c|c|c|}
\hline $\begin{array}{c}\text { Typology of } \\
\text { farming }\end{array}$ & $\begin{array}{c}\text { Constant return to } \\
\text { scale technical } \\
\text { efficiency (CRSTE) }\end{array}$ & $\begin{array}{c}\text { Variable return to } \\
\text { scale technical } \\
\text { efficiency (VRSTE) }\end{array}$ & $\begin{array}{c}\text { Scale } \\
\text { efficiency }\end{array}$ & $\begin{array}{c}\text { Type of } \\
\text { return } \\
\text { to scale }\end{array}$ \\
\hline Fieldcrops & 1 & 1 & 1 & - \\
\hline Horticulture & 0.833 & 1 & 0.833 & irs \\
\hline Wine & 0.139 & 0.591 & 0.235 & irs \\
\hline $\begin{array}{l}\text { Other permanent } \\
\text { crops }\end{array}$ & 0.437 & 0.94 & 0.465 & irs \\
\hline Milk & 1 & 1 & 1 & - \\
\hline $\begin{array}{l}\text { Other grazing } \\
\text { livestock }\end{array}$ & 1 & 1 & 1 & - \\
\hline Granivores & 1 & 1 & 1 & - \\
\hline Mixed & 0.593 & 1 & 0.593 & irs \\
\hline Mean & 0.75 & 0.941 & 0.766 & \\
\hline
\end{tabular}

irs stands for increasing return to scale

Findings in constant return to scale have pointed out the lowest value in wine farms, instead the highest value of technical efficiency has been found in specialized farms such as milk, granivores and other grazing livestock. This has corroborated the hypothesis according to which more specialized are farms higher in the technical efficiency; furthermore, agricultural enterprises with cows, pig or poultry have been more efficient than the other ones not specialized in livestock holding.

Roughly speaking, Bulgarian family farms have been partially able to efficiently use their family labour endowment and their land capital than other corporate and co-op enterprises as investigated in other European countries by lots of authors even if in general the agricultural coops are more technically efficient than family enterprises (Galluzzo, 2013; 2016; Kaneva, 2016). The increase return to scale (irs) on the variable return to scale (VRSTE) frontier in the DEA model has been assessed in 4 typologies of farming out of 8; no decrease return to scale (drs) has been found in all Bulgarian typologies of farming hence, a modest increase of input is able to rise more than a proportional a growth in output.

On average value over the time of investigation, Bulgarian farms stratified into function of their geographical localization in their 6 main NUTS 2 regions (Fig. 3), have been quite efficient considering the variable return to scale approach with an average value equal to 1 (Tab. 5); instead, in constant return to scale, the value of technical efficiency has been close to 0.99 and 
quite close to the optimal efficiency threshold. The increase return to scale on the variable return to scale (VRSTE) frontier in the DEA model has been assessed in the Northern Central region the tertiary and secondary sector is predominant and the agriculture is rarefied enough. As shown in table 5, the average value of the variable return to scale (VRSTE) has underlined results more efficiently in all Bulgarian regions compared to the constant return to scale approach (1 versus 0.99).

Tab 5. Technical efficiency in Bulgarian farms part of FADN stratified into different NUTS 2 regions. Source: elaboration on data http://ec.europa.eu/agriculture/rica/database/database_en.cfm

\begin{tabular}{|l|c|c|c|c|}
\hline \multicolumn{1}{|c|}{ region } & $\begin{array}{c}\text { Constant return to } \\
\text { scale technical } \\
\text { efficiency } \\
\text { (CRSTE) }\end{array}$ & $\begin{array}{c}\text { Variable return to } \\
\text { scale technical } \\
\text { efficiency } \\
\text { (VRSTE) }\end{array}$ & $\begin{array}{c}\text { Scale } \\
\text { efficiency }\end{array}$ & $\begin{array}{c}\text { Type of } \\
\text { return } \\
\text { to scale }\end{array}$ \\
\hline Northwestern & 1 & 1 & 1 & - \\
\hline Northern Central & 0.943 & 1 & 0.943 & irs \\
\hline Northeastern & 1 & 1 & 1 & - \\
\hline Southeastern & 1 & 1 & 1 & - \\
\hline Southern Central & 1 & 1 & 1 & - \\
\hline Southwestern & 1 & 1 & 0.99 & - \\
\hline mean & 0.99 & 1 & & \\
\hline
\end{tabular}

irs stands for increasing return to scale

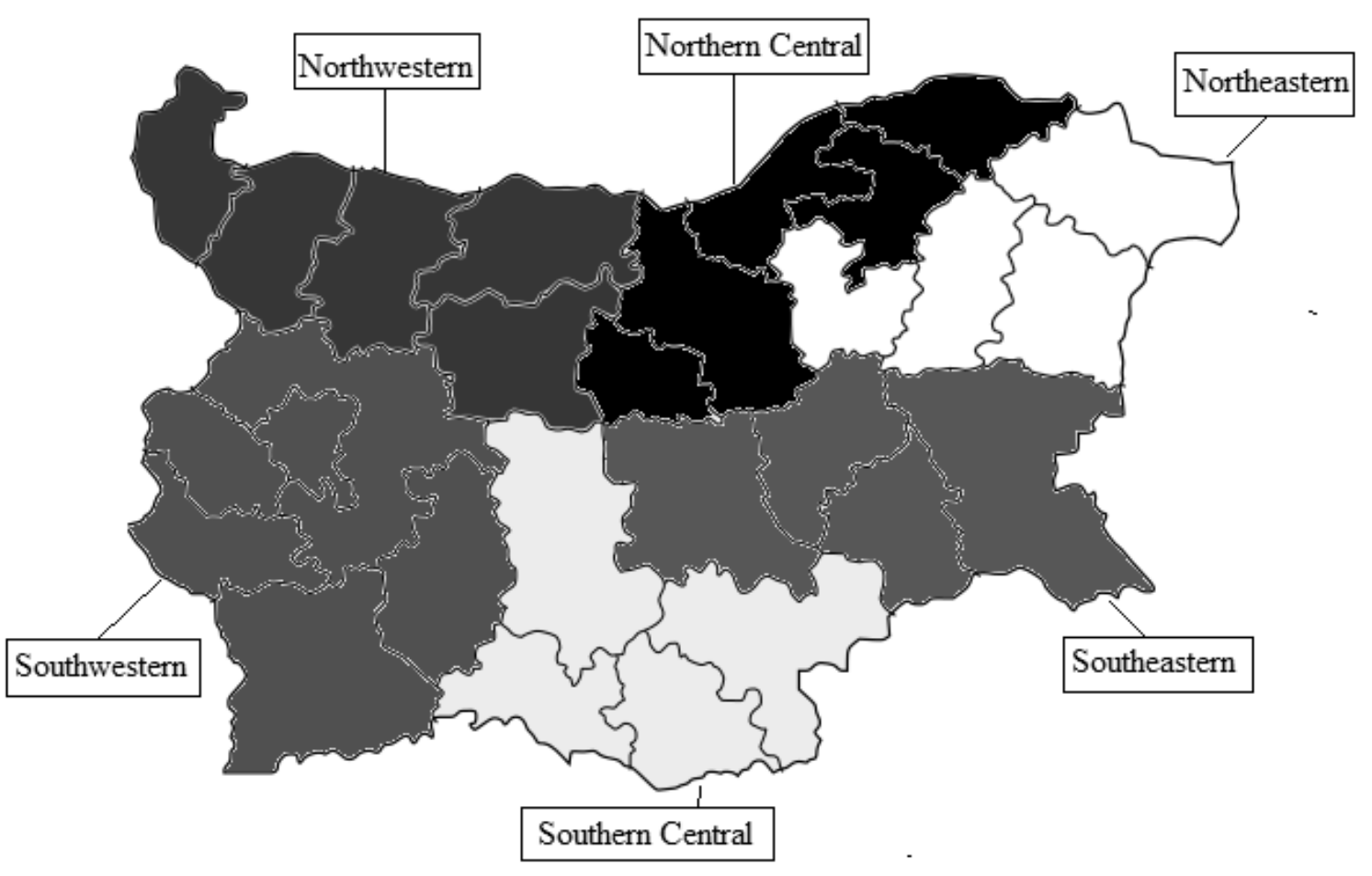

Fig 3. Main NUTS 2 regions in Bulgaria. 


\section{Conclusions and discussion}

As a consequence of the enlargement of the European Union, Bulgarian farms have benefited from financial subsidies allocated in favour of disadvantaged rural areas and other indirect payments and subsidies disbursed by the CAP. Findings in Bulgaria have corroborated, as argued by other authors, the direct link between productive specialization in farm and technical efficiency (Kopeva et al., 2012; Kaneva, 2016; Gorton and Davidova, 2004; Mathijs and Vranken, 2001). In fact, dairy farms, farms with animals (pig and poultry) and farms specialized in corn, cereals and wheat have had the highest level of technical efficiency due to an efficient use of labour capital and other input. Focusing the attention on the scale efficiency towards mixed, other permanent crops and wine farms in Bulgaria, results have been very modest. Comparing outcomes in this research to other findings assessed in several previous studies, it emerges that specialised Bulgarian enterprises such as dairy and crop farms have had the highest level of scale efficiency which has been very close to the optimal threshold equal to 1 as proposed by other authors (Mathijs and Vranken, 2001).

In general, the typology of management and ownership in Bulgarian farms is a predominant factor driving the efficiency in agricultural enterprises more than the productive specialization (Mathijs and Vranken, 2001; Gorton and Davidova, 2004; Kaneva, 2016), even if the productive specialization such as cereal and horticulture have been able to impact on the efficiency of Bulgarian farms as investigated in 2005-2007 by several scholars (Kopeva et al., 2012; Kaneva, 2016). Comparing results of technical efficiency in this research to others carried out by Kopeva et al. in 2012 and Kaneva in 2016, the main significant differences emerge. Firstly, there has been an increase of typology of farms technically efficient whose value of technical efficiency has been equal to 1 or very close to the optimal threshold equal to 1 . However, findings in this research compared to some proposed by Kaneva in 2016 have pointed out in granivores and in other grazing livestock farms the best results in technical efficiency with the exception of dairy and horticulture farms, which in contrast, have had a value under 1. Furthermore, in 2012, Kopeva et al. in a sample of farms have found an average value of technical efficiency in Bulgarian wine farms close to 0.6, instead outcomes in this research have been very modest and equal to 0.13 and 0.59 in constant and also in variable return to scale.

Comparing the average values of efficiency in all Bulgarian farms and in other agricultural enterprises assessed in several European countries, such as Romania, Slovenia and also Italy, findings have underlined a higher level of technical efficiency partially due to an increase of usable agricultural surface able to maximise the efficiency of labour capital and investments as argued by many authors and mentioned in the introduction paragraph.

Bulgarian farms have not been more sensitive to economic recession, which did not affect the level of technical efficiency in farms. In general, outcomes have not underlined significant differences among regions over the time of investigation in terms of economic efficiency of farms, which has implied stable features of agrarian Bulgarian regions and the positive impacts of pre-accession funds in reducing socio-economic imbalances among farms. Summing up, it is important to increase financial subsidies allocated by the second pillar of the Common Agricultural Policy in order to get the level of technical and economic efficiency better in Bulgarian farms even if perspectives for the future seem to be in favour of a significant shrinking of financial funds towards the rural development with the consequence of stimulating the permanent emigration from the countryside and the socio-economic marginalization in Bulgarian farms.

Small farms have received different typologies of subsidies from the Common Agricultural Policy with positive effect towards a significant change in farm specialization with effect on the technical efficiency, even if findings in lots of different European countries have pointed out a dissimilar impact of some financial subsidies such as decoupled payments to the technical efficiency (Latruffe et al., 2017; Latruffe and Nauges, 2014). Consequently, the role and function of direct funds allocated by the National Rural Development Plan and by decoupled payments in the first pillar of the CAP need a specific and particular attention by public authorities in the phase of rural planning for the next seven-year time 2021-2027 aimed at getting better the technical efficiency and competitiveness of Bulgarian farms. 
In order to increase the level of technical efficiency, as argued by Domanska et al. in 2014 and by Galluzzo in 2013, it is fundamental to rethink the strategic role of financial subsidies allocated by the CAP. In fact, it is pivotal to support on one hand the introduction of new technologies and the growth of the land capital endowment in terms of farm size and on the other hand, to reduce the fragmentation with the consequence to diminish costs and implement the labour capital efficiency.

The second pillar of the Common Agricultural Policy both in Bulgaria and also in all new member states of the European Union has to incentive the level of technology in farms and the use of labour saving techniques. Recent studies proposed by Turčeková et al., 2015 have argued that the higher the level of subsidies allocated in supporting the environmental protection, the higher the level of efficiency is. Furthermore, Nowack et al. in 2015 have emphasized the impact of new technologies in farms pointing out that the best results in technical efficiency has been found in countries where the level of technology has been higher in agriculture and this should be the milestone for establishing strategies and priorities in National Rural Development Programs in many European nations.

Academic references

[1] Bachev, H. (2017). Sustainability level of Bulgarian farms. Bulgarian Journal of Agricultural Science, 23(1), 1-13.

[2] Bakucs, L. Z., Latruffe, L., Fertő, I. \& Fogarasi, J. (2010). The impact of EU accession on farms' technical efficiency in Hungary. Post-communist economies 22(2), 165-175. DOI: $10.1080 / 14631371003740639$.

[3] Battese, G. E. (1992). Frontier production functions and technical efficiency: a survey of empirical applications in agricultural economics. Agricultural Economics 7, 185-208. DOI: $10.1016 / 0169-5150(92) 90049-5$.

[4] Bhagavath, V. (2009). Technical Efficiency Measurement by Data Envelopment Analysis: An Application in Transportation. Alliance Journal of Business Research. Available at www.ajbr.org/. Accessed 15 May 2017.

[5] Bielik, P. \& Rajcaniova, M. (2004). Scale efficiency of agricultural enterprises in Slovakia. Agricultural Economics Czech, 50(8), 331-335.

[6] Bojnec, S. \& Latruffe, L. (2008). Measures of farm business efficiency. Industrial Management \& Data Systems 108(2), 258-270. DOI: 10.1108/02635570810847617.

[7] Bojnec, Š. \& Latruffe, L. (2009). Determinants of technical efficiency of Slovenian farms. Post-Communist Economies 21(1), 117-124. DOI: 10.1080/14631370802663737.

[8] Bojnec, Š., Fertő, I., Jámbor, A. \& Tóth, J. (2014). Determinants of technical efficiency in agriculture in new EU member states from Central and Eastern Europe. Acta Oeconomica, 64(2), 197-217. DOI: 10.1556/AOecon.64.2014.2.4.

[9] Bravo-Ureta, B. E., Solís, D., López, V. H. M., Maripani, J. F., Thiam, A. \& Rivas, T. (2007). Technical efficiency in farming: a meta-regression analysis. Journal of productivity Analysis 27(1), 57-72. DOI: 10.1007/s11123-006-0025-3.

[10] Camelia, B. \& Vasile, B. (2016). The economic farm size and sustainable value disparities between Romania and the EU States. Annals of the "Constantin Brâncuşi” University of Târgu Jiu, Economy Series 10(1), 50-57.

[11] Cesaro, L., Marongiu, S., Arfini, F., Donati, M. \& Capelli, M. G. (2009). Methodology for Analysing Competitiveness, Efficiency, and Economy of Scale [project deliverable]. Brussel: INEA. 
[12] Charnes, A. \& Cooper, W. W. (1962). Programming with linear fractional functionals. Naval Research Logistics Quarterly 9(3-4), 181-186. DOI: 10.1002/nav.3800090303.

[13] Charnes, A., Cooper, W. W. \& Rhodes, E. (1978). Measuring the Efficiency of Decision Making Units. European Journal of Operational Research 2(6), 429-444. DOI: $10.1016 / 0377-2217(78) 90138-8$.

[14] Chavas, J. P. \& Aliber, M. (1993). An analysis of economic efficiency in agriculture: a nonparametric approach. Journal of Agricultural and Resource Economics 18(1), 1-16.

[15] Coelli, T. (1996). Recent developments in frontier modelling and efficiency measurement. Australian Journal of Agricultural Economics 39(3), 219-245. DOI: 10.1111/j.14678489.1995.tb00552.x.

[16] Davidova, S. \& Latruffe, L. (2007). Relationships between technical efficiency and financial management for Czech Republic farms. Journal of Agricultural Economics 58(2), 269-288. DOI: $10.1111 /$ j.1477-9552.2007.00109.x.

[17] Davidova, S. M. (1991). Bulgarian farm structure: From paralysis to reform. Food Policy 16(3), 196-205. DOI: 10.1016/0306-9192(91)90085-X.

[18] Di Falco, S., Penov, I., Aleksiev, A. \& van Rensburg, T. M. (2010). Agrobiodiversity, farm profits and land fragmentation: Evidence from Bulgaria. Land use policy 27(3), 763-771. DOI: 10.1016/j.landusepol.2009.10.007.

[19] Domanska, K., Kijek, T. \& Nowak, A. (2014). Agricultural total factor productivity change and its determinants in European Union countries. Bulgarian Journal Agricultural Science, 20(6), 1273-1280.

[20] Doyle, J. \& Green, R. (1994). Efficiency and cross-efficiency in DEA: Derivations, meanings and uses. Journal of Operational Research Society 45(5), 567-578. DOI: $10.1057 /$ jors.1994.84.

[21] Farrell, M. J. (1957). The measurement of productive efficiency. Journal of Royal Statistical Society 120, 253-281. DOI: 10.2307/2343100.

[22] Galluzzo, N. (2013). Farm dimension and efficiency in Italian agriculture: a quantitative approach. American Journal of Rural Development 1(2), 26-32. DOI: 10.12691/ajrd-1-2-2.

[23] Galluzzo, N. (2015a). Technical and economic efficiency analysis on Italian smallholder family farms using Farm Accountancy Data Network dataset. Studies in Agricultural Economics 117(1), 35-42. DOI: 10.7896/j.1501.

[24] Galluzzo, N. (2015b). Analysis of impact of rural development subsides on cropping specialization in Bulgaria and Romania using FADN data [unpublished paper]. Available at http://ageconsearch.umn.edu. Accessed 15 May 2017.

[25] Galluzzo, N. (2016). An analysis of the efficiency in a sample of small Italian farms part of the FADN dataset. Agricultural Economics Czech 62, 62-70. DOI: 10.17221/37/2015AGRICECON.

[26] Garcia, P., Sonka, S. T. \& Yoo, M. S. (1982). Farm Size. Tenure. and Economic Efficiency in a Sample of Illinois Grain Farms. American Journal Agricultural Economics 64, 119-123. DOI: $10.2307 / 1241181$.

[27] Gorton, M. \& Davidova, S. (2004). Farm productivity and efficiency in the CEE applicant countries: a synthesis of results. Agricultural economics, 30(1), 1-16. DOI: 10.1111/j.15740862.2004.tb00172.x.

[28] Guth, M. (2015). Diversity of FADN milk farms in the regions of the European Union in 2011. Roczniki Naukowe Stowarzyszenia Ekonomistów Rolnictwa i Agrobiznesu, 17(3), 119-124.

[29] Guyomard, H., Latruffe, L. \& Le Mouël, C. (2006). Technical efficiency, technical progress and productivity change in French agriculture: Do subsidies and farms' size matter? 
[unpublished paper]. Available at:

https://www.researchgate.net/profile/Chantal_Mouel/publication/228378368_Technical_effi ciency_technical_progress_and_productivity_change_in_French_agriculture_Do_subsidies _and_farms'_size_matter/links/09e41508814dc6724f000000.pdf. Accessed 15 May 2017.

[30] Hadad, Y., Friedman, L. \& Hanani, M. Z. (2007). Measuring efficiency of restaurants using the data envelopment analysis methodology. Computer Modeling and New Technologies 11(4), 25-35.

[31] Kaneva, K. (2016). Efficiency and productivity of Bulgarian farms. Bulgarian Journal Agricultural Science, 22(2), 176-181.

[32] Kočišová, K. (2015). Application of the DEA on the measurement of efficiency in the EU countries. Agricultural Economics, 61(2), 51-62. DOI: 10.17221/107/2014-AGRICECON.

[33] Kopeva, D., Madjarova, S. \& Nikolova, N. (2012). Efficiency of Agricultural Production Units. [Working papers]. Sofia: University of National and World Economy.

[34] Kumbhakar, S. C. (1993). Short-Run Returns to Scale. Farm-Size and Economic Efficiency. The Review of Economics and Statistics, 75(2), 336-341. DOI: $10.2307 / 2109441$.

[35] Latruffe, L. (2010). Competitiveness, productivity and efficiency in the agricultural and agrifood sectors [Research paper]. Paris: OECD. DOI: 10.1787/5km91nkdt6d6-en.

[36] Latruffe, L. \& Nauges, C. (2014). Technical efficiency and conversion to organic farming: the case of France. European Review of Agricultural Economics, 41(2), 227-253. DOI: $10.1093 /$ erae/jbt024.

[37] Latruffe, L., Balcombe, K., Davidova, S. \& Zawalinska, K. (2004). Determinants of technical efficiency of crop and livestock farms in Poland. Applied Economics 36(12), 1255-1263. DOI: $10.1080 / 0003684042000176793$.

[38] Latruffe, L., Balcombe, K., Davidova, S. \& Zawalinska, K. (2005). Technical and scale efficiency of crop and livestock farms in Poland: does specialization matter? Agricultural Economics 32(3), 281-296. DOI: 10.1111/j.1574-0862.2005.00322.x.

[39] Latruffe, L., Bravo-Ureta, B. E., Carpentier, A., Desjeux, Y. \& Moreira, V. H. (2017). Subsidies and technical efficiency in agriculture: Evidence from European dairy farms. American Journal of Agricultural Economics 99(3), 783-799. DOI: 10.1093/ajae/aaw077.

[40] Latruffe, L., Fogarasi, J. \& Desjeux, Y. (2012). Efficiency, productivity and technology comparison for farms in Central and Western Europe: The case of field crop and dairy farming in Hungary and France. Economic Systems 36(2), $\frac{\text { 264 }}{278 .}$ DOI: $10.101 \overline{6 / j}$.ecosys.2011.07.002.

[41] Laurinavičius, E. \& Rimkuvienè, D. (2017). The Comparative Efficiency Analysis of EU Members Agriculture Sectors. Rural Sustainability Research, 37(332), 10-19. DOI: 10.1515/plua-2017-0002.

[42] Manos, B., Bournaris, T., Chatzinikolaou, P., Berbel, J. \& Nikolov, D. (2013). Effects of CAP policy on farm household behaviour and social sustainability. Land Use Policy 31 , 166-181. DOI: 10.1016/j.landusepol.2011.12.012.

[43] Marongiu, S., Cesaro, L., Latruffe, L. \& Desjeux, Y. (2010). L'Efficienza tecnica delle aziende agricole di montagna: analisi dei dati RICA e confronto fra montagna Italiana e Francese. [Unpublished paper]. Available at: https://aisre.it/images/old_papers/Marongiu.pdf. Accessed 15 May 2017.

[44] Mathijs, E. \& Swinnen, J. F. (2001). Production organization and efficiency during transition: An empirical analysis of East German agriculture. The Review of Economics and Statistics 83(1), 100-107. DOI: 10.1162/003465301750160072. 
[45] Mathijs, E. \& Vranken, L. (2001). Human capital, gender and organisation in transition agriculture: measuring and explaining the technical efficiency of Bulgarian and Hungarian farms. Post-Communist Economies 13(2), 171-187. DOI: 10.1080/14631370120052654.

[46] Mathijs, E., Blaas, G. \& Doucha, T. (1999). Organisational form and technical efficiency of Czech and Slovak farms. MOST: Economic Policy in Transitional Economies, 9(3), 331344. DOI: $10.1023 / \mathrm{A}: 1009524807421$.

[47] Nowak, A., Kijek, T. \& Domanska, K. (2015). Technical efficiency and its determinants in the European Union agriculture. Agricultural Economics-Czech, 61(6), 275-283. DOI: 10.17221/200/2014-AGRICECON.

[48] Papadas, C. T., Dahl, D. C. (1991). Technical efficiency and farm size: a non-parametric frontier analysis [Working paper]. Minneapolis: University of Minnesota.

[49] Paul, C., Nehring, R., Banker, D. \& Somwaru, A. (2004). Scale economies and efficiency in US agriculture: are traditional farms history? Journal of Productivity Analysis, 22(3), 185205.

[50] Turčeková, N., Svetlanská, T., Kollár, B. \& Záhorský, T. (2015). Agri-environmental performance of EU member states. Agris On-line Papers in Economics and Informatics, 7(4), 199-208.

[51] Vēveris, A., Leimane, I. \& Krieviña, A. (2007). Efficiency analysis of agricultural sector in Latvia compared to other EU countries, based on FADN data. In Ivans, U., ed., Economic Science for Rural Development (pp. 13-19). Jelgava: Latvian Academy of Agriculture and Forestry Sciences.

[52] Záhorský, T. \& Pokrivčák, J. (2016). Determinants of efficiency in agriculture in CEE countries [Unpublished paper]. DOI: 10.15414/isd2016.s12.11.

Other Sources

[53] European Commission Agriculture and Rural Development (2014). Concept of FADN. Available at www.ec.europa.eu/agriculture/rica/concept_en.cfm. Accessed 15 May 2017. 